\title{
O RÁDIO A SERVIÇO DA EDUCAÇÃO BRASILEIRA: UMA HISTÓRIA DE NOVE DÉCADAS
}

\author{
Roseane Andrelo ${ }^{1}$ \\ (UNESP/BAURU)
}

\begin{abstract}
RESUMO
O cenário que delineia este trabalho é marcado pela centralidade que as tecnologias da informação e comunicação ocupam na sociedade e pela necessidade de incorporá-las na educação, seja a distância ou presencial. Entre as TICs, foi escolhido para análise o rádio, pela penetração que tem no Brasil e pela história de quase noventa anos de ações pontuais educativas. Vale ressaltar, contudo, que o rádio tem servido historicamente à educação, mas parece ter atendido com eficiência as concepções mais conservadoras, como o processo centrado no professor-emissor, na transmissão de conteúdos estagnados e na avaliação que cobrava a memorização de aspectos pontuais do conteúdo ensinado. Porém, o sistema educacional brasileiro sofreu reformas importantes nos anos 1990 e esse quadro traz novas exigências para o rádio na educação - formar ouvintes críticos, cidadãos conscientes, pessoas com sensibilidade estética, ética etc. Portanto, é necessária uma avaliação sistemática das reais possibilidades educativas do veículo. Sendo assim, esta pesquisa tem como objetivo principal resgatar as principais ações educativas no rádio, relacionando-as à regulamentação da educação no Brasil. Para isso, pauta-se em pesquisa bibliográfica e documental.

Palavras-chave: rádio na educação; história da educação; educação pelas mídias; educação às mídias
\end{abstract}

\section{RADIO SUPPORTING THE BRAZILIAN EDUCATION: A NINE DECADES HISTORY}

\begin{abstract}
The scenario that outlines this research project is characterized by the centrality of ICT on society and the necessity of having them embedded on education, both face-to-face and distance learning. Amongst the available ICT, the medium radio has been chosen due to its popularity within Brazilian society, as well as its 90 years of initiatives applied on education. Although the radio seems to be historically useful to education, it has been supporting more conservative approaches, such as teaching centred practices, simply transmitted lessons and assessment based on memorization. On the other hand, Brazilian educational system has been changed since the early 90s, and those reforms brought new challenges to the radio on education, such as training critical listeners, concerned citizens, people with aesthetic sensibility, ethical standards etc. Thus, a systematic assessment of the real educational possibilities of the radio is even more necessary. This research project aims to retrieve the most prominent educational initiatives using the radio, connecting them to the Brazilian regulatory framework on Education. The methodology consists of desk research and official documents analyses.

Keywords: Radio on education; History of Education; Education through the media; Media education
\end{abstract}




\section{Introdução}

O papel de destaque que as tecnologias de informação e comunicação (TICs) assumiram na sociedade, sobretudo a partir dos anos 1990, coloca cada vez mais em pauta a discussão sobre seu uso na educação. Sob as mais diversas perspectivas, discute-se a utilização das TICs, seja na educação a distância ou presencial, como metodologia de ensino ou como conteúdo escolar, ao reconhecer a necessidade de formação para uma leitura crítica das tecnologias.

Essa discussão é garantida por documentos oficiais, como as Diretrizes Curriculares Nacionais para o Ensino Fundamental (1998), que sugerem a apropriação de novas linguagens e tecnologias de comunicação, e a Lei de Diretrizes e Bases $n^{\text {o }}$ 9.394/96 que salienta a importância do conhecimento das formas contemporâneas de linguagem no ensino médio e formaliza a proposta de educação a distância. Há, também, fatores situacionais, como a própria centralidade das tecnologias na sociedade e o papel inegável da escola de preparar os alunos para um mundo cada vez mais midiatizado, segundo um dos pressupostos do presente trabalho.

Mais do que um modismo, a apropriação das TICs no universo escolar merece uma discussão aprofundada. Caso contrário, elas correm o risco de tornarem-se meros recursos didáticos para ensinar determinados conteúdos, sem que haja qualquer reflexão sobre suas características, ou mesmo serem encaradas como o fim do processo, em uma visão tecnicista da educação. Refletir sobre a questão passa obrigatoriamente pela análise das ações já desenvolvidas. Afinal, apesar da atualidade da temática, uma rápida olhada na história da educação no Brasil permite verificar várias ações envolvendo TICs antes mesmo da regulamentação do setor, na década de 1930. No caso específico do uso do rádio, objeto da presente pesquisa, a Rádio Sociedade do Rio de Janeiro, primeira emissora regular brasileira, surgiu em 1923 com o objetivo de "levar a cada canto um pouco de educação, de ensino e de alegria".

Este trabalho resgata as principais ações educativas no rádio, relacionando-as ao contexto em que estavam inseridas. O objetivo deste resgate é propiciar um olhar histórico ao uso da mídia na educação, relacionando os principais fatos à regulamentação da educação no Brasil. Para isso, utiliza-se de pesquisa bibliográfica e documental.

\section{Experiências educativas no rádio}

A proposta de transmitir educação pelo rádio é tão antiga quanto a história do veículo. Desde a década de 1920, marcada pelo surgimento oficial do rádio no Brasil, até a atualidade, foram feitas várias experiências, embora com diferentes conceitos de educação.

No caso da Rádio Sociedade do Rio de Janeiro, Edgard Roquette-Pinto, um dos fundadores da emissora, ao lado de Henrique Charles Moritze e de um grupo de intelectuais da Academia Brasileira de Ciências, dizia:

O rádio é o jornal de quem não sabe ler; é o mestre de quem não pode ir à escola; é o divertimento gratuito do pobre; é o animador de novas esperanças; o consolador do enfermo; o guia dos sãos, desde que o realizem com espírito altruísta e elevado. (TAVARES, 1999, p.8).

Para Tavares (1999), os ideais de Roquette-Pinto podem ser explicados pelo momento político e cultural da época. A chegada dos imigrantes europeus, intensificada na década anterior, contribuiu para a efervescência política, tanto a anarquista quanto a 
comunista. Nesse contexto, destaca-se o movimento sindical e a organização de várias greves.

Não apenas os trabalhadores estavam mobilizados na luta por seus ideais. Em 1922, surge o tenentismo, a partir do descontentamento de militares com a corrupção no processo político, dominado pelas oligarquias. No panorama cultural, destaca-se a Semana de Arte Moderna, que aconteceu no mesmo ano da chegada oficial do rádio no Brasil. $\mathrm{O}$ movimento é marcado pela redefinição dos parâmetros da pintura, da escultura e da literatura brasileira. Há uma vontade de transformar o país vinda de várias frentes trabalhadores, intelectuais e militares, cada um a sua maneira (FERRARETTO, 2001).

No que diz respeito à educação, propriamente dita, o contexto também era de efervescência. Foi na década de 1920, que surgiram as reformas estaduais - em São Paulo, tendo à frente Sampaio Dória; em Minas Gerais, com Francisco Campos; no Distrito Federal, com Fernando Azevedo e, na Bahia, com Anísio Teixeira. Além dos Estados, houve uma discussão em nível nacional, envolvendo um grupo de educadores com idéias renovadoras sobre o ensino e que culminou, em 1924, na fundação da Associação Brasileira de Educação. Com o objetivo de implantar uma política nacional de educação, a entidade elaborou propostas que versavam, entre outros tópicos, sobre a universalização do ensino primário leigo, obrigatório e gratuito, sob responsabilidade do Estado (AZEVEDO, 2001).

É nesse contexto que surgem emissoras como a Rádio Sociedade do Rio de Janeiro e a Rádio Educadora de São Paulo. No caso da rádio carioca, cujo início se deu em 1923, os microfones foram utilizados por intelectuais e cientistas, como o físico alemão Albert Einstein e o poeta italiano Filippo Tommaso Marinetti, criador do movimento futurista. A emissora tinha um caráter elitista não só pelo conteúdo que veiculava, como palestras com temática científica e músicas clássicas, mas também pelo fato de poucas pessoas terem um aparelho de rádio.

Em 1925, a Rádio Sociedade deu início à parte instrucional, com uma perspectiva mais popular de educação. Veiculava aulas de francês, português, geografia, história do Brasil, higiene, silvicultura, química, história natural e física. Havia também transmissões de concertos e espetáculos teatrais (FEDERICO, 1982).

Ao analisar os pronunciamentos de Roquette-Pinto, percebe-se que a proposta educativa da Rádio Sociedade era voltada à elevação do nível intelectual e educativo da população. Seu slogan era "trabalhar pela cultura dos que vivem em nossa terra e pelo progresso do Brasil". Porém, havia o preço, os requisitos formais e "a falta de cuidado com os níveis sócio-linguísticos, repertório da provável audiência.” (FEDERICO, 1982, p. 48).

Em 1926, Roquette-Pinto publicou na Revista Eléctron o artigo "Radioeducação do Brasil", no qual traça um plano para transformar em cinco ou seis anos a mentalidade popular do país. Segundo ele, cada Estado fundaria uma radioescola, totalizando vinte "poderosas estações", fornecidas através de concorrência pública. Já os municípios limítrofes entrariam em acordo para subvencionar um sistema de rádio, a radioescola municipal (SALGADO, 1946).

Três anos depois, em 1929, houve um movimento feito por revistas e jornais em prol da radiodifusão escolar. Nesse ano, a Diretoria de Instrução Pública de São Paulo instalou, para experiência, um aparelho de rádio receptor no Grupo Escolar Prudente de Morais. Porém, no dia 30 de agosto de 1929, a Folha da Noite, de São Paulo, chamava a atenção para a falta de experiência dos professores encarregados das emissões escolares.

A década de 1930 chega em um contexto de transformações na sociedade brasileira. Com o crack de 1929, não havia mais como obter financiamentos para a compra dos imensos estoques de café. Ao mesmo tempo, com a saturação do mercado mundial, caem 
as exportações do produto. O resultado foi a diminuição da entrada de capitais. Apesar desse cenário difícil, o Brasil contou com a acumulação primitiva de capital e ampliação do mercado interno, o que permitiu o desenvolvimento industrial, em um momento de crise (ROMANELLI, 1988).

Com as atenções voltadas ao mercado interno, produtos que antes eram importados passaram a ser fabricados no país. Essa situação, à qual se soma o crescimento urbano, interferiu na educação, uma vez que cresceu a pressão para aumentar a oferta de ensino (AZEVEDO, 2001). A industrialização necessitava de mão-de-obra alfabetizada e com o mínimo de qualificação ao trabalho. "A predominância do setor agrícola na nossa economia, aliada a formas arcaicas de produção e à baixa densidade demográfica e de urbanização, respondia, portanto, pela escassa demanda social de educação." (ROMANELLI, 1988, p. 60).

Essa situação muda na década de 1930, com a implantação do capitalismo no Brasil, embora isso não aconteça de forma homogênea, já que a expansão da demanda escolar desenvolveu-se apenas em locais onde aumentaram as relações de produção capitalista.

Ao assumir o poder, o Governo Provisório (1930-1934) buscou condições de infraestrutura administrativa, com novos modelos de intervenção estatal, como o surgimento de políticas setoriais. Desta forma, criou ministérios, como o da Educação e Saúde Pública, tendo Francisco Campos como seu primeiro ministro. Esse foi o marco da regulamentação nacional do setor educativo. Entre as medidas tomadas, constam os decretos que instituem o regime universitário, reformam os ensinos secundário e comercial e criam o Conselho Nacional de Educação e o Conselho Consultivo do Ensino Comercial, responsáveis pelo estabelecimento das diretrizes nacionais para os ensinos primário, secundário, superior e técnico profissional e também pela unificação delas via poder central (AZEVEDO, 2001).

A educação, que já vinha sendo discutida de forma sistemática desde a criação da Associação Brasileira de Educação, faz cada vez mais parte da agenda pública. Algumas das ações da Associação foram a publicação do Manifesto dos Pioneiros da Educação Nacional, em 1932, e as lutas posteriores em torno do projeto de lei das Diretrizes e Bases da Educação Nacional. O documento reivindicava laicidade do ensino público, gratuidade, obrigatoriedade entre outros itens e defendia uma reação contra a estrutura educacional vigente, considerada verbalista e artificial.

Mais do que isso, tratava a educação como um problema social. "Ao proclamar a educação como um problema social, o Manifesto não só estava traçando diretrizes novas para o estudo da educação no Brasil, mas também estava representando uma tomada de consciência, por parte dos educadores, até então praticamente inexistente." (ROMANELLI, 1988, p.150). Muitas das reivindicações foram incluídas na Constituição de 1934.

Interessante realçar que o manifesto (1932) já pregava o uso de meios de comunicação na educação. "[...] a escola deve utilizar, em seu proveito, com a maior amplitude possível, todos os recursos formidáveis, como a imprensa, o disco, o cinema e o rádio [...]." Um dos argumentos para a inserção desses meios na escola era a extensão territorial do País.

A perspectiva educativa do rádio, como foi demonstrado, também era compartilhada pelas primeiras emissoras brasileiras. Porém, esse quadro começa a ser alterado a partir da década de 1930 . O período é marcado pela regulamentação do veículo no Brasil, com destaque para dois decretos: o 20.047, de 1931, que intimava as transmissoras a aumentar seu potencial de antena, e o 21.111 , de 1932 , que permitiu a 
publicidade no rádio. O resultado foi a profissionalização e a implantação do caráter comercial do rádio.

No que diz respeito à Rádio Sociedade do Rio de Janeiro, os dois decretos foram determinantes. Roquette-Pinto acreditava que o aumento de potência só era possível nas sociedades organizadas em base comercial, e a venda de publicidade não era permitida pelos estatutos da emissora (ROQUETTE-PINTO, 2002/2003). Para evitar que ela se tornasse um empreendimento lucrativo, Roquette-Pinto preferiu doá-la, em 1936, ao Ministério da Educação e Saúde Pública, que tinha como ministro Gustavo Capanema (governo Getúlio Vargas, 1934-1945). A Rádio MEC (atual Rádio MEC AM, do Rio de Janeiro), como passou a ser chamada, foi doada com uma condição registrada em termo assinado com o governo:

As instalações serão gratuitamente transferidas ao Ministério da Educação e Saúde, que, em compensação, se obriga a não utilizar a emissora para outros fins senão o desenvolvimento da cultura popular e jamais permitir a publicidade comercial ou a propaganda política. (FEDERICO, 1982, p. 46).

Com a doação, em 1937 foi criado o Serviço de Radiodifusão Educativa, uma iniciativa do governo de Getúlio Vargas, que foi dirigido por Roquette-Pinto até 1943. O órgão era "destinado a promover, permanentemente, a irradiação de programas educativos." Porém, apesar das diretrizes estritamente educativas defendidas pelo órgão, grande parte dos projetos sofreu interferência do Departamento de Imprensa e Propaganda (DIP) (MOREIRA, 1991).

Com o Estado Novo (1937-1945), não apenas o rádio sofre intervenção. A Constituição de 1937 trata a educação com mais restrição. A gratuidade e a obrigatoriedade do ensino são mantidas, mas a ênfase é dada ao ensino profissional, destinado, principalmente, às classes populares. "[...] oficializou-se o dualismo educacional: ensino secundário para as elites e ensino profissionalizante para as classes populares." (LIBÂNEO et al, 2003, p. 143).

No que diz respeito ao ensino secundário, o decreto-lei $\mathrm{n}^{\circ} 4244$ previa um ensino patriótico, que englobava a compreensão dos problemas e dos ideais da nação. De um lado baseava-se nos princípios do populismo nacionalista e fascista. De outro, tinha conteúdo literário acadêmico (ROMANELLI, 1988).

O dualismo e o patriotismo são percebidos na programação da Rádio MEC, composta de cursos (literatura francesa e inglesa ou de silvicultura prática), de lições (português, francês, italiano, geografia e história natural), de palestras seriadas (síntese das marés etc) e do programete quarto de hora (literário, infantil etc). Além dessa programação, "a emissora era forçada a transmitir solenidades oficiais e semi-oficiais, muitas vezes impróprias a uma irradiação, o que contribuiu sobremaneira para que os ouvintes se desabituassem de sintonizá-la.” (SALGADO, 1946, p. 72). A rádio divulgava, também, longas conferências, de até quatro horas.

No mesmo período, surgiram outras iniciativas no gênero. Em 1936, a partir da sugestão do então secretário estadual da Agricultura, Israel Pinheiro, o Estado de Minas Gerais ganhou uma emissora mantida pelo governo, a Rádio Inconfidência. O objetivo era levar conhecimento ao agricultor e o primeiro programa chamava-se Meia-hora do fazendeiro. Em seus três primeiros anos de transmissão, já transformado em Hora do fazendeiro, recebeu 25 mil cartas. "Era a idéia de extensionismo rural presente na segunda década de existência do rádio no Brasil.” (FERRARETTO, 2001). 
Destaca-se ainda a criação, em 1933, da Rádio Escola Municipal do Distrito Federal, sugerida por Roquette-Pinto e levada à frente pelo educador Anísio Teixeira. A emissora, hoje chamada de Rádio Roquette-Pinto, começou funcionando em uma pequena sala nos fundos do Teatro Municipal do Rio de Janeiro. Antes da transmissão das aulas, eram enviados folhetos aos inscritos, pelo correio, com os esquemas das lições.

Os alunos, por sua vez, enviavam à emissora os trabalhos e faziam contato por carta, telefone e visitas. Após um ano de sua criação, a emissora já havia recebido 10.800 trabalhos. Assim, estabelecia "[...] o contato direto entre emissora e ouvinte e o desenvolvimento de uma didática especial para o ensino radiofônico." (MOREIRA, 1991, p. 18).

A separata do regimento interno da Rádio Escola, edição de agosto de 1941, no artigo $3^{\circ}$, dizia que "as aulas dos cursos instituídos pela Rádio Escola, serão obrigatoriamente ouvidas nas escolas, estabelecimentos de ensino e cursos a que se destinem." (SALGADO, 1946, p.68). O autor lembra que a programação era composta de hinos e canções escolares, do boletim de atos e instruções da diretoria geral, além de lições e sessões artísticas, como o curso de "estilos arquitetônicos".

Para Salgado (1946, p.93), o Estado de São Paulo foi o que mais se preocupou com o rádio educativo. O decreto ${ }^{\circ}$ 5.884, de abril de 1933, instituiu o Código de Educação de São Paulo, no capítulo XI, Do Serviço de Rádio e Cinema Educativo, cujo objetivo era "[...] colocar ao alcance da escola as conquistas da técnica moderna, no campo da cinematografia e do rádio." Os estabelecimentos de ensino deveriam instalar aparelhos de rádio. Além disso, foi criada uma rádio-escola para irradiar programas de informação e orientação organizados pelo Departamento de Educação; a hora certa; o hino nacional; comunicados oficiais; conferências e palestras e boletim meteorológico.

Foi nas décadas de 1940 e 1950 que surgiram programas específicos de educação. Um exemplo é o Universidade no Ar, lançado em 1941 pela Rádio Nacional do Rio de Janeiro, encampada um ano antes por Getúlio Vargas. O objetivo do programa era oferecer orientação metodológica aos professores do ensino secundário, com cursos de letras, ciências, didática e pedagógica, entre outros. No seu primeiro ano, o projeto registrou 4.829 radioalunos.

Os cursos eram gratuitos e qualquer professor podia se inscrever. Às vezes, recebiam resumos mimeografados das aulas. O aproveitamento do curso era verificado por trabalhos feitos pelos alunos que, se satisfatórios, recebiam certificados. Segundo Salgado (1946, p.87), o projeto levava "às mais afastadas regiões cursos semelhantes aos ministrados nas faculdades de Filosofia, nos grandes centros urbanos do Brasil".

Em 1944, através da Portaria no 18, o Ministério da Educação instituiu concurso para selecionar nova cartilha destinada à alfabetização de adultos, operários e trabalhadores do campo. A Portaria estabelecia que "as cartilhas deveriam ser preparadas de sorte que pudessem ser também utilizadas para ensino por meio de rádio.” (COSTA, 1956, p.61). O Ministério nunca deu retorno sobre o concurso, muito provavelmente pelas mudanças políticas de 1945.

$\mathrm{Na}$ década de 1940, entre as reformas feitas pelo ministro Gustavo Capanema, chamadas de Leis Orgânicas do Ensino, percebe-se a preocupação do governo em engajar as indústrias na qualificação da mão-de-obra, afinal, o Estado precisava satisfazer a necessidade de consumo interno com produtos nacionais, sem importar trabalhadores especializados. Criou-se, então, em 1942, o Serviço Nacional de Aprendizagem Industrial (SENAI) e, em 1946, o Serviço Nacional de Aprendizagem Comercial (SENAC), dando início a um sistema de ensino paralelo ao oficial, a partir de convênio com a Confederação Nacional das Indústrias e a Confederação Nacional do Comércio (ROMANELLI, 1988). 
Em 1947, o sistema SENAC e SESC lançou, em São Paulo, um programa com o mesmo nome - o Universidade no Ar - com o objetivo de atingir a classe operária do Interior. Segundo Costa (1956), os professores liam suas lições ao microfone e os alunos, reunidos em núcleos de recepção, ouviam a aula e depois debatiam sobre o assunto, sob orientação de um professor-assistente. Depois das aulas, os estudantes recebiam textos, pelo correio, e faziam provas. $\mathrm{O}$ autor conta que, no primeiro curso, matricularam-se 1.531 alunos, dos quais 839 fizeram as provas e 635 conseguiram habilitar-se.

Em 1949, o professor João Ribas da Costa elaborou um plano para a criação de escolas radiofônicas, que visavam a alfabetização de adultos. A ideia era fazer uma grande cadeia de emissoras de onda média, sem fins lucrativos, em algumas áreas do Nordeste, preferencialmente nas regiões com alta densidade demográfica, onde as estações eram raras.

O professor argumentava que o custo do sistema rádio-educativo, em cinco anos, seria inferior ao do sistema tradicional em um só ano. A economia, segundo ele, se basearia na substituição de milhares de professores por poucos especialistas. "De acordo com o plano, os postos de recepção seriam confiados a monitores - pessoas de ambos os sexos, com um mínimo de conhecimentos, que auxiliariam a tarefa do professor-locutor, a título de colaboração gratuita." (COSTA, 1956, p. 45).

Além da questão econômica, João Ribas da Costa destacava como vantagem de sua proposta o que chamou de "universalidade da influência". "Enquanto o sistema escolar comum só atinge os adultos que se matricularem e forem assíduos, a atividade do Sistema Rádio-Educativo se estende a todos quantos forem capazes de ouvir, inclusive, portanto, os não matriculados e, até, os próprios cegos." (COSTA, 1956, p. 47).

A proposta foi rejeitada sob a alegação de que o ensino da leitura "é tecnicamente impossível de se realizar através do rádio, por ser indispensável o contato direto entre o professor e o aluno". Porém, segundo Costa, menos de um ano depois, o técnico de Educação do Estado do Rio de Janeiro, professor Geraldo Jañuzzi, sem conhecer o plano, idealizou e dirigiu um curso de alfabetização pelo rádio, na emissora ZYM-7, da cidade fluminense de Marquês de Valença.

Na década de 1950, aumenta a oferta de emprego, com a criação de infra-estrutura de comunicações, transporte e energia, porém, falta mão-de-obra qualificada. "A educação, portanto, passa a ser encarada como o único caminho disponível, para as classes médias, de conquistar postos e, para as empresas, de preencher seus quadros." (ROMANELLI, 1988, p. 206). Surgem iniciativas focadas no público adulto, sem que o sistema educacional respondesse de forma satisfatória à demanda existente.

Em 1957, tiveram início os cursos básicos do Sistema de Rádio Educativo Nacional (SIREN), patrocinados pelo MEC e dirigidos por Ribas Costa. Um ano depois da criação do SIREN, 11 emissoras irradiavam cursos básicos que visavam erradicar o analfabetismo, número que saltou para 47 emissoras em 1961. "Apesar do relativo sucesso do Sistema, ele foi extinto em 1963 e incorporado à Rádio Educadora de Brasília." (MOREIRA, 1991, p. 20). A autora cita duas razões para o fim do projeto: a preocupação excessiva com os recursos materiais, em detrimento do preparo de pessoal e do controle de resultados, e as oscilações de natureza política.

Do fim do Estado Novo, em 1945, até o golpe militar de 1964, a educação volta de forma mais intensa ao debate nacional. Nesse período de democratização, há um movimento por uma educação popular e outro em defesa da educação pública. O primeiro predomina na educação não-formal e na educação de jovens e adultos. O segundo concentra-se na educação escolar formal, tendo como um de seus momentos mais importantes nos debates acerca da LDB (GADOTTI, 1993). 
De acordo com a Constituição de 1946, a União deveria legislar sobre as diretrizes e bases da educação nacional, propondo os requisitos mínimos para que elas fossem estipuladas. Assim, o então ministro da Educação, Clemente Mariani (governo Eurico Gaspar Dutra, 1946-1951), formou uma comissão de educadores para elaborar um projeto de reforma geral da educação nacional. Encaminhada à Câmara Federal em 1948, a lei 4.024 foi aprovada apenas em 1961. "Em essência, pois, a lei nada mudou. A sua única vantagem talvez esteja no fato de não ter prescrito um currículo fixo e rígido para todo o território nacional, em cada nível e ramo.” (ROMANELLI, 1988, p.181).

Para alguns analistas, a promulgação da Lei de Diretrizes e Bases da Educação Nacional respondeu mais aos interesses dos setores privatistas do que aos interesses sociais do momento.

Não se definiram as diretrizes de um novo padrão educativo que implicasse a inovação estrutural do sistema de ensino no país, ao mesmo tempo em que continuaram sem respostas os problemas fundamentais da destinação social da educação, do conteúdo do ensino e da relação entre educação e o trabalho. (AZEVEDO, 2001, p. 38).

Frente a esse quadro, as questões educacionais foram incluídas “[...] entre as reformas de base reivindicadas nas amplas mobilizações que tomaram conta do país no início dos anos 60, e que conduziram à quebra do pacto populista." (AZEVEDO, 2001, p. $38)$.

Além disso, difundiu-se a idéia de educação enquanto um meio de mobilização política, sobretudo em determinadas práticas de alfabetização de adultos, que procuravam ir além de ações baseadas no ensino da leitura, da escrita e do contar. "Não formulando nenhum questionamento sobre a realidade mas, pelo contrário, procurando sempre dissimula-la, essas práticas estavam perfeitamente sintonizadas com a reprodução social das estruturas sócio-econômicas existentes." (GERMANO, 1989, p. 23). Alguns exemplos de campanhas que visavam práticas alternativas à educação convencional são o Método Paulo Freire, o Movimento de Educação de Base (MEB); o Movimento de Cultura Popular; e a Campanha "De pé no chão também se aprende a ler", realizada em Natal $(\mathrm{RN})$.

O MEB surgiu em 1961 e era ligado a grupos da Igreja Católica. Regulamentado por decreto presidencial, teve como idealizador Dom Eugênio Salles. Uma das atividades do movimento foi a criação de escolas radiofônicas. A iniciativa, supervisionada pela Conferência Nacional dos Bispos do Brasil (CNBB), marcava a participação da Igreja Católica nas experiências com o rádio educativo. Embora, como ressalta Moreira (1991, p. 20), "as atividades da Igreja nesse campo já existiam, na verdade, desde a metade da década de 1950, quando frei Gil Bonfim, da Ordem Franciscana, apresentou às autoridades eclesiásticas um projeto de programação diária de aulas de alfabetização".

O Norte, Nordeste e Centro-Oeste brasileiros foram o palco de atuação do Movimento de Educação de Base que, além da alfabetização, tinha como meta a conscientização, a mudança de atitudes e a instrumentação das comunidades receptoras.

A conscientização representa, para o MEB, o reconhecimento, pelo educando, de seus valores, da significação vivencial de seu trabalho de homem no mundo. $\mathrm{O}$ MEB entende que ela é intrínseca à própria educação, pois significa ajudar alguém a tomar consciência do que ele é (consciência de si), do que são os outros (comunicação dos dois sujeitos) 
e do que é o mundo (coisa intencionada), sem dúvida os três pólos de toda educação integral. (IPEA, 1976, p. 27).

A prática de conscientização motivou o surgimento da idéia de animador popular.

Definida como um 'processo de estruturação de comunidades, progressivamente assumido por seus próprios membros, a partir de seus elementos de liderança', a proposta de animação popular tornou-se o centro da ação educativa do MEB e as Escolas Radiofônicas passaram a representar apenas um instrumento dentro desse contexto. (MOREIRA, 1991, p.21).

A autora menciona alguns pontos do Movimento: "ler, escrever e interpretar textos com situações e vocabulários próprios das áreas rurais"; "distinguir as relações entre as estruturas sociais, econômicas, políticas e religiosas"; "saber utilizar a legislação e as potencialidades econômicas da comunidade" e "desenvolver o conhecimento sobre as técnicas de trabalho em grupo".

A programação era dividida entre aulas para escolas radiofônicas (oferecem ao monitor subsídios para a alfabetização e pós-alfabetização), cursos radiofônicos (aos monitores e comunidades atingidas, visando transmitir informações e possibilitar a formação de grupos comunitários em função de temas como sindicalismo, saúde etc) e programas especiais (caráter recreativo e sócio-cultural para atingir público mais amplo que o da escola). A transmissão era feita pelas emissoras pertencentes à Diocese e a recepção acontecia nas escolas radiofônicas e nos grupos de audiência organizados para os cursos radiofônicos (IPEA, 1976).

Porém, o momento pelo qual o País passava - de ditadura militar - já não combinava mais com as propostas do MEB e tampouco com a perspectiva de descentralização prevista na LDB. "Em 1964, o golpe dos militares provocou novamente o fortalecimento do Executivo e a centralização das decisões no âmbito das políticas educacionais." (LIBÂNEO et al, 2003, p.137). O Movimento de Educação de Base enfrentou situações difíceis e a palavra conscientização passou a ser interpretada como uma ameaça à ordem.

A participação da sociedade civil na discussão sobre educação ficou cada vez mais restrita e as escolas e municípios cada vez mais dependentes da União. Ela, por sua vez, traça uma política educacional que busca atender exigências quantitativas da demanda social, sem que isso aconteça de forma satisfatória.

Como a meta é baseada na quantidade, a educação a distância via rádio parecia adequada. Nos anos 1970, o governo federal implantou o Projeto Minerva, um programa de 30 minutos diários, veiculado de segunda à sexta, e de uma hora e 15 minutos, aos sábados e domingos. Tinha cunho informativo-cultural e educativo, visando o ensino a distância, com transmissão obrigatória por todas emissoras. A programação era gerada via Embratel pela Rádio MEC, do Rio de Janeiro, para todo o País. Exceção apenas das áreas não cobertas pela rede de telecomunicações. Nesses locais, as emissoras recebiam os programas gravados em fitas. No ar de outubro de 1970 até outubro de 1989, o projeto tinha produção regionalizada, concentrada no eixo Sul-Sudeste, com uma distribuição centralizada.

Ele visava à complementação do trabalho dos sistemas educativos tradicionais e educação continuada, podendo abranger qualquer nível de escolaridade. A recepção acontecia de forma isolada, com cada ouvinte em sua residência, ou organizada, para alunos reunidos em grupos de 30 e 50, que acompanham as aulas sob orientação de um 
monitor escolhido na própria classe, sendo que cada radioposto tinha um aparelho receptor e o acompanhamento era feito em apostilas, com a classe podendo funcionar em escolas, quartéis, clubes etc (IPEA, 1976).

Para Ferraretto (2001, p.162), o projeto Minerva foi uma resposta do governo militar aos movimentos de educação popular anteriores ao golpe. Além disso, o uso do veículo de comunicação tinha como norte uma visão tecnicista, típica da ditadura. "Nesse contexto de um processo pedagógico voltado apenas a instrumentalizar o indivíduo para o trabalho, sem refletir criticamente sobre a realidade, o governo determina horários obrigatórios para a transmissão de programas educativos".

No que diz respeito ao uso da televisão na educação a distância, destacou-se nesse período o Telecurso $2^{\circ}$. Grau, lançado em 1978, e o Telecurso $1^{\circ}$. Grau, em 1981. Os projetos que, a partir de 1995, foram transformados em Telecurso 2000, foram uma iniciativa da Fundação Roberto Marinho. As aulas eram veiculadas pela TV e contavam com apoio de material impresso, vendido em bancas de jornal. Os fascículos, bastante explicativos, determinavam o caminho que o aluno deveria seguir. "Tudo se enquadrava, portanto, no conceito de 'instrução programada' em que o aluno é conduzido, por meio de uma sequiência suave e cartesiana, do mais simples ao mais complexo, de uma premissa a uma conclusão". (MICHELOTO, 2006, p. 38).

Entre os conteúdos trabalhados, verificados previamente pelos censores a serviço do regime militar, constavam as disciplinas Educação Moral e Cívica e Organização Social e Polícia do Brasil, que visavam o "treinamento do cidadão responsável”. "A concepção do Telecurso quanto aos direitos do cidadão resumia-se à sua dimensão puramente individual, formal, desvinculada da realidade social e política". (MICHELOTO, 2006, p. 38). Apesar disso, para o autor, o Telecurso foi um projeto inovador que incorporou novas tecnologias, chegando a populações de regiões distintas, com carência de serviços educacionais.

Também data da década de 1970 o Sistema Avançado de Comunicações Interdisciplinares (Projeto SACI), surgido a partir de uma proposta feita pela Comissão Nacional de Atividades Espaciais à Nasa. Com o plano aceito, foi estabelecida como zona piloto para o projeto o Rio Grande do Norte, com a participação de estações de rádio e de televisão. Em 1973 e 1974, dois mil professores leigos foram treinados e 16.000 alunos de escolas de primeiro grau receberam emissões dos programas de ensino. O projeto terminou, segundo Barros (2003), por razões políticas e o Instituto Nacional de Pesquisas Espaciais (INPE) fechou o centro de tecnologia educacional. A ação dependia de satélites, "[...] uma tendência inviável para os interesses políticos porque outras agências brasileiras passaram a solicitar a adoção de satélites para outros fins, principalmente a expansão das telecomunicações." (BARROS, 2003, p. 49; 50).

$\mathrm{Na}$ década de 1970, o Centro Nacional de Recursos Humanos do Instituto do Planejamento (IPLAN) fez um diagnóstico do rádio no Brasil, dentro do Sistema Avançado de Tecnologias Educativas (Projeto SATE), substituído mais tarde por um conjunto de programas de teleducação, coordenado pelo Ministério da Educação e da Cultura. Ele apresenta a seguinte análise (IPEA, 1976):

a) Produção - predominam programas expositivos e de diálogo construído, o que torna monótona a aula radiofônica; pouca redundância; linguagem difícil e inadequada ao público; ritmo de locução acima da possibilidade de acompanhamento; o apelo à atividade dos alunos durante as transmissões é insuficiente e o interesse não é mantido; aulas curtas;

b) Recepção - pouca ênfase na recepção organizada ou controlada; grande rotatividade entre o pessoal de recepção; supervisão não sistemática;

c) Transmissão - unificação do horário inadequada, pois não permite atender à clientela com diferentes horários de trabalho e de estudos; a revisão semanal aos sábados 
inadequada, porque não se faz repetição total dos programas; horário de domingo voltado a fins culturais, o mesmo previsto para toda a radiodifusão;

d) Planejamento e pesquisa - faltam estudos exploratórios para servir de base ao planejamento; a programação é feita sem estudos sobre o público-alvo; não há aproveitamento da realimentação, visando introdução de correções.

Em fevereiro de 1999, foi assinado um convênio entre o então ministro da Educação, Paulo Renato Souza (governo Fernando Henrique Cardoso, 1995-2002), e a Associação Brasileira das Emissoras de Rádio e Televisão (ABERT), que substitui o Projeto Minerva. De acordo com o convênio, as emissoras associadas à Abert deveriam veicular aos sábados e domingos três pequenos programas, entre as 6 horas e as 22 horas. A grande maioria dos programas tratava de ações do MEC, como o Exame Nacional do Ensino Médio ou o extinto Provão, terminando com a leitura de um poema ou trecho de um conto ou romance. Havia, ainda, uma participação do ministro, que lia e respondia cartas de ouvintes.

Em 2003, o Ministro da Educação, Cristovam Buarque (governo Luiz Inácio Lula da Silva, 2003-2011), assinou um convênio similar, em vigor até 31 de dezembro de 2006, com o presidente da ABERT, Paulo Machado de Carvalho Neto, para veiculação de programas educativos no rádio e na televisão. O convênio garante ao $\mathrm{MEC}$ a divulgação gratuita de mensagens institucionais e de utilidade pública durante cinco minutos diários, na forma de inserções de 30 segundos a um minuto, em todas as emissoras de televisão e rádios AM e FM filiadas à entidade. Além disso, as emissoras devem transmitir três programas aos sábados e domingos. Eles serão produzidos e distribuídos pelo MEC. A proposta é veicular também assuntos sobre alfabetização, ensino básico, tecnológico e superior, educação especial e a distância.

No que diz respeito à educação a distância, um dos programas mantidos pelo governo federal, através da Secretaria de Educação a Distância, é o Rádio Escola, que "[...] desenvolve ações que utilizam a linguagem radiofônica para o aprimoramento pedagógico de comunidades escolares, o desenvolvimento de protagonismos cidadãos e o treinamento de grupos profissionais." (MEC, 2006). A proposta, segundo exposto no site do MEC, é usar as tecnologias para gerar melhorias sociais, principalmente ao "ampliarem as oportunidades de apreensão do saber através das variadas mídias existentes”.

$\mathrm{Na}$ área educacional, essas novas tecnologias potencializam as mais antigas, integrando-se a elas e proporcionando uma democratização da produção e recepção do conhecimento e das informações (informações aqui entendidas como patrimônio público, de acesso aberto a todo o povo brasileiro).

A interatividade cada vez maior dos meios de comunicação exige o desenvolvimento de habilidades específicas nos que dela fazem uso. Caso contrário, aparecerá uma nova forma de exclusão social: o analfabetismo dos meios de comunicação.

O Rádio Escola, ciente dessa nova realidade, tem por princípio essa "educação para, sobre e na mídia", oferecendo para os que partilham da realidade de nossa cultura o pleno exercício da cidadania. (MEC, 2006).

O Rádio Escola é composto de três tipos de produtos de educação a distância: a série do professor, do aluno e do radialista. $\mathrm{O}$ material inclui programas de rádio, gravados em fitas cassetes ou CDs, e um guia impresso com instruções de uso e sugestões de atividades pedagógicas. Em um primeiro momento, os kits eram enviados pelo correio. Atualmente, estão disponibilizados no site do MEC. 
A série dos professores tem como proposta ser um recurso pedagógico na capacitação de alfabetizadores. Os programas, de capacitação continuada, apresentam subsídios para o trabalho com alunos, como atividades e também questões a ser discutidas. A série de alunos é um material didático de apoio, elaborado a partir do tema cantoria de viola nordestina. "Seu objetivo é informar o aluno sobre a origem, história, características e a importância da cantoria de viola nordestina no contexto da cultura popular brasileira". Já a série do radialista disponibiliza 60 programas, com três minutos cada, para as emissoras de rádio interessadas em veiculá-los. O foco é a alfabetização, com sugestões de atividades para o alfabetizador.

Da parte do governo federal há, também, ações pontuais envolvendo o rádio, como o projeto Saberes das Águas, que teve início em 2005 como parte do Programa Brasil Alfabetizado. Barcos-escola e rádios comunitárias foram utilizados para reforçar o projetopiloto de alfabetização de pescadores que o MEC e a Secretaria Especial de Aqüicultura e Pesca desenvolvem em Xique-Xique, Remanso, Barra e Pilão Arcado, municípios baianos localizados às margens do Rio São Francisco.

Além de adotar medidas mais diretas no que diz respeito ao uso do rádio na educação, como as iniciativas descritas, há o incentivo, pelo Governo Federal, para a utilização do rádio na educação, em vários documentos do MEC. Conforme já foi mencionado, o Plano Nacional de Educação (2001) formaliza a proposta de educação a distância utilizando diversos meios de comunicação, entre eles, o rádio. As Diretrizes Curriculares Nacionais para o Ensino Fundamental (1998) permitem a apropriação de novas linguagens e tecnologias de comunicação e a LDB 9.394/96 deu autonomia para a elaboração do projeto pedagógico. Ou seja, desde o surgimento do rádio, o governo brasileiro vem incentivando o seu uso na educação.

Atualmente, a incorporação das mídias no ambiente escolar tornou-se um objeto de estudo que, cada vez mais, atrai pesquisadores. Um dos resultados são parcerias desenvolvidas entre universidades e escolas. Ao desenvolver programas educativos com foco nos meios de comunicação, é possível fazer uma distinção entre duas correntes: a educação às mídias, que pressupõe a leitura crítica dos meios de comunicação, e a educação pelas mídias, baseada no uso de suporte midiático, seja na educação a distância ou presencial. O pressuposto deste trabalho é que as duas devem ser integradas. Afinal, não é mais possível ensinar com o rádio, a televisão, o jornal ou a internet sem ensinar ao mesmo tempo a competência midiática e a análise das mídias tão presentes na vida cotidiana da escola (PICHETTE, 1996).

Desta forma, as TICs deixam de ser vistas como mero suportes. São várias as razões para promover a formação em mídia. Uma delas é a centralidade que os meios de comunicação têm na sociedade, afinal assumem o papel de mediador entre o público e a realidade concreta, seja pelo conteúdo que veicula ou mesmo pela forma como é construída, trocando a linearidade pela fragmentação e, consequentemente, gerando mudanças de sensibilidade, sobretudo entre os jovens. Outro ponto diz respeito à noção de representação, ou seja, entende-se que os meios de comunicação não refletem a realidade, mas a representam, o que invalida a noção de transparência, de "janela", pela qual se vê o mundo.

Entre os vários exemplos possíveis, em Bauru, a Universidade do Sagrado Coração realiza, como atividade de extensão dos cursos de Comunicação Social, oficinas a escolas públicas que queiram implantar rádio interna. Em 2006, foram capacitados alunos das escolas estaduais Francisco Alves Brizola e Padre Antonio Lima. A primeira recebeu verba do MEC e da UNESCO para montar a rádio. A segunda, que já tinha rádio, recebeu verba para montar uma TV interna. 
Em São Paulo, uma das experiências é o projeto Educom.rádio: educomunicação pelas ondas do rádio, um curso de extensão que começou a ser desenvolvido em 2001, pelo Núcleo de Comunicação e Educação da Universidade de São Paulo, com professores de ensino fundamental da rede municipal de São Paulo. As atividades fizeram parte do projeto Vida, que visava diminuir a violência nas escolas. Professores, funcionários de escolas, alunos e membros da comunidade da rede pública do município de São Paulo participaram de cursos de capacitação, aprendendo a elaborar uma programação radiofônica e a utilizar os recursos disponíveis em estúdio.

\section{Algumas considerações}

Em resumo, as experiências relatadas demonstram que, apesar de um uso social marcado pela comercialização de espaços, o rádio brasileiro é visto, desde o início, com um potencial à educação, embora com perspectivas bastante distintas. $\mathrm{O}$ contexto muda, a expectativa de formação dos cidadãos também e isso é refletido no rádio. Em um primeiro momento, buscou-se educar a população para a cultura erudita (década de 1920). Depois, a necessidade de formação de mão-de-obra para atender à economia nacional alterou a concepção de educação, ensinando técnicas de uso prático (década de 1930). Ideais patrióticos também foram altamente divulgados (década de 1940). Com o fím do populismo, a educação é vista como forma de mobilização política (década de 1960). O cenário se altera durante a ditadura militar e a educação assume um caráter tecnicista, com pouca reflexão.

No final do século XX e início do XXI, cresce a discussão sobre o uso dos meios de comunicação de massa na educação, mas com outras expectativas. A ideia de aula ou mesmo de veiculação de conteúdo tipicamente escolar é praticamente abandonada. As emissoras comerciais se limitam a transmitir programetes de prestação de serviços, como de prevenção à dengue e de cuidados com o meio ambiente. As emissoras educativas apostam em formatos considerados culturais, dando espaço a estilos musicais diferenciados com informações sobre eles.

Especificamente na educação escolar, o governo federal criou programas de formação de professores para o uso das TICs e usa formatos midiáticos para isso. Mesmo sendo oferecidos a distância, eles ainda atingem um número restrito de docentes. Algumas escolas, por sua vez, com apoio de organizações não-governamentais, universidades e algumas prefeituras, criam suas próprias "emissoras", que funcionam em circuito fechado. Nestes casos, importa menos a qualidade da transmissão do que o fato de os próprios alunos serem os protagonistas. A educação pela mídia é acrescida da educação às mídias.

Essa visão parte da certeza que as tecnologias da informação e da comunicação ocupam um lugar central na sociedade, embora o acesso a elas seja desigual. Dos vários aspectos dessa centralidade, é essencial reconhecer seu papel na educação não-formal, tanto pelo conteúdo difundido quanto pela forma fragmentada com que ele chega ao público. O reflexo dessa centralidade pode ser percebido na educação formal, seja quando as TICs são utilizadas como método de ensino, como conteúdo, no caso dos programas de educação às mídias, ou mesmo sem que haja intencionalidade, já que os atores sociais levam informações, valores e formas de ver o mundo que foram construídos com a ajuda das tecnologias.

Cabem à educação formal a sistematização e a reflexão sobre esses aprendizados. $\mathrm{O}$ pressuposto é que o papel da escola deve ir além do ensino de conteúdos escolares, trabalhados de forma estanque e, muitas vezes, sem relação com a realidade dos alunos. Não se trata de defender uma educação utilitarista, mas de situá-la nos contextos 
socioeconômico, político e cultural, cada vez mais complexos. Essa perspectiva inclui a educação às mídias, assim como os demais temas considerados transversais, como ética, saúde, meio ambiente, orientação sexual e pluralidade cultural. Desta forma, mais do que a veiculação de programas educativos pelo rádio, é essencial transformar as mídias em conteúdo educativo.

\section{REFERÊNCIAS}

AZEVEDO, Janete M. Lins de. O Estado, a política educacional e a regulação do setor educação no Brasil: uma abordagem histórica. In: Ferreira, Naura; Aguiar, Marcia (Org.). Gestão da educação: impasses, perspectivas e compromissos. São Paulo: Cortez, 2001.

BARROS, Daniela Melaré Vieira. Educação a distância e o universo do trabalho. Bauru: Edusc, 2003.

BRASIL. Lei de Diretrizes e Bases da Educação Nacional nº 9.394/96, de 20 de dezembro de 1996 [LDB]. Estabelece as diretrizes e bases da educação nacional. Disponível em: 〈http://www.planalto.gov.br/ccivil/LEIS/L9394.htm>. Acesso em: $1^{\text {o }}$. dez. 2007.

Ministério da Educação. Diretrizes Curriculares para o Ensino Fundamental. Brasília: Câmara de Educação Básica do Conselho Nacional de Educação, 1998. Disponível em: <http://www.diariooficial.hpg.com.br/fed_res_cne_ceb_021998.htm >. Acesso em: 1 dez. 2007.

Lei $n^{0} 10.172$ de 9 de janeiro de 2001. Estabelece o Plano Nacional de Educação. Disponível em: <htpp://www.planalto.gov.br>. Acesso em: 28 mai. 2005.

COSTA, João Ribas. Educação fundamental pelo rádio: alfabetização de adultos e cultura popular por meio de sistemas radiofônicos e recepção organizada. São Paulo: Empresa Gráfica Editora Guia Fiscal, 1956.

FEDERICO, Maria Elvira Bonavita. História da comunicação: rádio e TV no Brasil. Petrópolis: Vozes, 1982.

FERRARETTO, Luiz Artur. Rádio: o veículo, a história e a técnica. $2^{\mathrm{a}}$ ed. Porto Alegre: Editora Sagra Luzzatto, 2001.

GADOTTI, Moacir. História das idéias pedagógicas. São Paulo: Ática, 1993.

GERMANO, José Willington. Lendo e aprendendo: a campanha de pé no chão. $2^{\mathrm{a}}$. ed. São Paulo: Autores Associados; Cortez, 1989.

INSTITUTO DE PLANEJAMENTO ECONÔMICO E SOCIAL [IPEA]. Rádio educativo no Brasil: um estudo. Brasília: IPEA, 1976.

JACQUINOT, Geniève. Image et pedagogie: analyse sémiologique du film à intention didatique. Paris: Presses Universitaires de France, 1977.

LIBÂNEO, J.C.; OLIVEIRA, J.F.; TOSCHI, M.S. Educação escolar: políticas, estrutura e organização. São Paulo: Cortez, 2003.

MICHELOTO, Antônio Ricardo. A cidadania do Telecurso: memórias de um projeto de educação popular. Revista Educação Popular, Uberlândia, jan.-dez. 2006, nº 5, p. 35-40. 
Disponível em: <http:// www.revistadeeducacaopopular.proex.ufu.br>. Acesso em: 24 jan. 2008.

MINISTÉRIO DA EDUCAÇÃO [MEC]. Rádio Escola. Disponível em:

<http://portal.mec.gov.br/seed>. Acesso em: 27 jul. 2006.

MOREIRA, Sonia Virgínia. O rádio no Brasil. Rio de Janeiro: Rio Fundo Ed., 1991.

PICHETTE, Michel (Org.). Vivre avec les médias: ça s'apprend! Québec/Montreal : Centrale de l'enseignement du Québec ; Service aux collectivités de l'Université du Québec à Montreal, 1996.

ROMANELLI, Otaíza de Oliveira. História da educação no Brasil (1930/1973). $10^{\text {a }}$ ed. Petrópolis: Vozes, 1988.

ROQUETTE-PINTO, Vera Regina. Roquette-Pinto, o rádio e o cinema educativo. Revista USP, São Paulo, no 56, dez. 2002-fev. 2003, p. 10-15.

SALGADO, Álvaro. A radiodifusão educativa no Brasil. Rio de janeiro: Imprensa Nacional, 1946.

TAVARES, Reynaldo. Histórias que o rádio não contou: do galena ao digital, desvendando a radiodifusão no Brasil. $2^{\mathrm{a}}$ ed. Ed. Harbra, 1999.

\footnotetext{
${ }^{1}$ Universidade Estadual Paulista "Júlio de Mesquita Filho" (UNESP/BAURU)

Email: roseane.andrelo@faac.unesp.br
}

Recebido em janeiro/2012

Aprovado em maio/2012 